\title{
Application of pulsed arterial resuscitation in a rabbit model of hemorrhagic shock
}

\author{
Wendong Sun, M.D., ${ }^{1}$ Zhihui Shao, M.D., ${ }^{2}$ Haisong Xu, M.D., ${ }^{2}$ Wusi Qiu, M.D., ${ }^{2}$ Jiahua Sun, M.D. ${ }^{2}$
}

${ }^{1}$ Department of Orthopedics, Shaoxing People's Hospital, Shaoxing Hospital of Zhejiang University, Shaoxing-PRC

${ }^{2}$ Department of Neurosurgery, Hangzhou Second Hospital, College of Medicine, Hangzhou Normal University, Hangzhou-PRC

\begin{abstract}
BACKGROUND: Hemorrhagic shock is characterized by tissue hypoperfusion caused by a sharp reduction in the effective circulating volume of blood. The key to successful resuscitation lies in eliminating the shock as soon as possible while simultaneously restoring blood perfusion to vital organs. We present the applicability of pulsed arterial blood reinfusion for resuscitation of hemorrhagic shock.

METHODS: Sixty rabbits were randomly assigned to resuscitation and control groups. A rabbit hemorrhagic shock model was developed by bloodletting from the carotid artery. The dynamic changes in blood pressure, urine output, blood lactate, and other indicators were measured.

RESULTS: Compared with the control group, the mean arterial pressure (MAP), pulse pressure, and urine output were significantly higher in the resuscitation group at $60 \mathrm{~min}$ (MAP: $83.67 \pm 3.90 \mathrm{vs.} 38.19 \pm 3.50 \mathrm{mmHg}, \mathrm{p}<0.00$ I; pulse difference: I6.46 \pm 2.21 vs. I $0.27 \pm 2.99 \mathrm{mmHg}, \mathrm{p}<0.00 \mathrm{I}$; urine output: $3.68 \pm 0.74 \mathrm{vs}$. $0.10 \pm 0.05 \mathrm{~mL} \cdot \mathrm{kg}^{-1} \cdot \mathrm{min}^{-1}, \mathrm{p}<0.00 \mathrm{I}$ ), whereas the serum lactate level was significantly lower $(3.82 \pm 0.50$ vs. $6.49 \pm 0.6 \mathrm{I} \mathrm{mmol} / \mathrm{L}, \mathrm{p}<0.00 \mathrm{I})$. In addition, the resuscitation group had a significantly higher lactate clearance rate (30 min: $0.26 \% \pm 0.1$ I \% vs. $0.25 \% \pm 0.14 \%, p<0.001 ; 60 \mathrm{~min}: 0.30 \% \pm 0.09 \%$ vs. $0.67 \% \pm 0.26 \%$, $\mathrm{p}<0.00 \mathrm{I}$ ) than the control group.
\end{abstract}

CONCLUSION: Pulsed arterial resuscitation might be useful for emergency treatment of hemorrhagic shock.

Keywords: Artery; hemorrhagic shock; pulse; resuscitation.

\section{INTRODUCTION}

In recent decades, great progress has been made in the resuscitation of hemorrhagic shock, enabling most patients to receive timely medical treatment. ${ }^{[1-7]}$ However, while early mortality has been significantly reduced, long-term mortality rate remains high. The main causes of death secondary to hemorrhagic shock are tissue hypoperfusion, major bleeding, and reperfusion injury, which can lead to multiple organ dysfunction syndrome. ${ }^{\left[{ }^{-12]}\right.}$ Hemorrhagic shock is characterized by tissue hypoperfusion caused by a sharp reduction in the effective circulating volume of blood. Therefore, the key to successful resuscitation lies in eliminating the shock as soon as possible while simultaneously restoring blood perfusion to

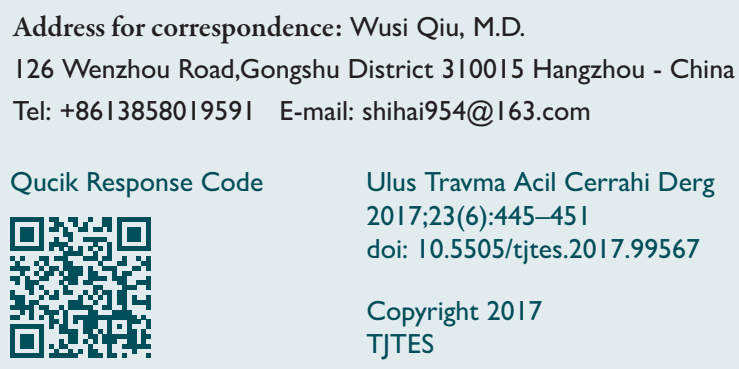

vital organs, terminating ischemia and hypoxia in the cells, and rebuilding balance of the body's oxygen supply and demand. Irrespective of whether the traditional liberal fluid resuscitation or the newly proposed restricted fluid resuscitation method is used, a large amount of resuscitation fluids such as crystalloids, hypertonic saline and synthetic colloids need to be infused in a short time..$^{[2,4,13-15]}$ However, because of the high risk of peripheral venous collapse in these patients, the implementation of both these methods is difficult. In addition, the liquid is infused into a vein and thus cannot directly increase the perfusion to the heart, brain, kidney, and other organs; furthermore, the sudden rise in intravascular hydrostatic pressure and continuing decrease in plasma colloid osmotic pressure can lead to tissue edemas, such as pulmonary edema and cerebral edema, associated with increased intracranial pressure. ${ }^{[2,4,14,16]}$

Rectifying tissue edema caused by fluid overload is currently a popular topic in fluid resuscitation research..$^{[1,15]}$ In recent years, the available arterial puncture procedures have gradually become more sophisticated. The carotid artery is located relatively superficially, is close to the heart, and has many receptors involved in regulating blood circulation on its vessel walls. In addition, as the blood supply of the brain depends on 
the bilateral common carotid arteries, if the liquid is infused through one side of the common carotid artery, the infusion will not cause reduction in blood flow to the brain because of the compensation from the other side. Thus, arterial resuscitation may represent an effective option for critically ill patients in whom conventional intravenous resuscitation is not suitable. In this study, we aimed to explore the applicability of pulsed arterial blood reinfusion for the resuscitation of hemorrhagic shock using a rabbit model of hemorrhagic shock. Furthermore, we hypothesized that pulsed arterial reinfusion would be more effective than the traditional liberal fluid resuscitation.

\section{MATERIALS AND METHODS}

\section{Animal Grouping and Preparation}

Sixty male or female (non-pregnant) rabbits, with a body weight of 1.5-2.5 kg, were provided by the Animal Center of the Southeast University School of Medicine (Animal Certificate of Conformity: SCXK [Su] 20I2-0003). The rabbits were I:I randomly assigned using a random number table to the resuscitation or control group, with 30 rabbits in each group. After they were weighed, the rabbits were anesthetized by injecting $20 \%$ urethane solution $(5 \mathrm{~mL} / \mathrm{kg})$ through the ear vein and were fixed on the bench. Subsequently, the rabbits were subjected to a midline neck incision. The common carotid arteries were isolated and catheterized to collect blood samples with heparinization. The end of the catheter was connected to a biological signal acquisition system through a sterilized three-way connector (i.e., sterilized T-branch threeway pipe) to trace the arterial blood pressure, electrocardiography parameters, and other vital indicators. ${ }^{[5]}$ The bladder was exposed and catheterized to collect urine specimens. The end of the catheter was connected to a biological signal acquisition system to monitor urine output.

The research protocol was approved by the Institutional Review Board and the ethical committees of the Clinical Medical College of Hangzhou Normal University.

\section{Preparation of the Hemorrhagic Shock Model}

The model was established using the described method with slight modifications. ${ }^{[4,17]}$ After catheterization was completed and stabilized for $10 \mathrm{~min}$, the blood pressure and heart rate were recorded, and blood samples were obtained as the baseline parameters. Next, blood was withdrawn at $2 \mathrm{~mL} / \mathrm{min}$ from the common carotid artery through a $50-\mathrm{mL}$ syringe. The blood received an immediate anti-coagulant treatment with $\mathrm{pH}$ control and was stored for the subsequent blood reinfusion. Within 30 min after bloodletting, the mean arterial pressure (MAP) had decreased to $50 \%$ of the baseline value, which was maintained for $30 \mathrm{~min}$.

\section{Pulsed Arterial Blood Reinfusion Resuscitation}

The resuscitation began after the shock had been stable for
$30 \mathrm{~min}$. Within $5 \mathrm{~s}$, rabbits in the resuscitation group were reinfused with $5 \mathrm{~mL}$ of blood from the carotid artery, followed by $5 \mathrm{~mL}$ of saline (using the same lavage tube). This procedure was repeated every $5 \mathrm{~min}$. Rabbits in the control group were reinfused into the venous system with $5 \mathrm{~mL}$ of blood from the ear vein at a constant speed, followed by $5 \mathrm{~mL}$ of saline (using the same lavage tube). This procedure was repeated every 5 min. The volume of the reinfused blood was $40 \%$ of the total blood volume removed.

\section{Monitoring of indicators}

Animal systolic blood pressure, diastolic blood pressure, MAP, pulse pressure changes, and urine output were monitored throughout the experiment, and the changes in lip color were continuously observed. At 0, 30, 60 (start of resuscitation), and 90 min after the hemorrhagic shock model was established, blood was withdrawn to measure the lactate level (kit provided by Nanjing Jiancheng Bioengineering Research Institute, Jiangsu, China).

\section{Statistical analysis}

All data were analyzed using SPSS 19.0 software (SPSS Inc., Chicago, IL). Quantitative data are presented as mean \pm standard deviation $(x \pm s)$ and were analyzed using non-paired t-tests. Qualitative data were analyzed using chi-squared tests. For all analyses, the level of significance was set at $p<0.05$.

\section{RESULTS}

\section{General Condition}

At 10 min after bloodletting, the animals began to show cyanosis of the lips, which gradually intensified during the shock process. At the beginning of the resuscitation, there were no significant changes in the lip color. However, when the reinfused blood volume amounted to approximately $30 \%$ of the total blood loss, the cyanosis on the lips of the rabbits in the resuscitation group began to subside. At the late stage of the resuscitation, the cyanosis had almost disappeared. In the control group, there were no significant changes in the cyanosis, with the rabbit lips exhibiting a dark purple color at the late stage of the resuscitation.

\section{Mortality Rates}

No experimental animals died during the surgical preparation stage or the $30-\mathrm{min}$ shock period. At $60 \mathrm{~min}$, there were no deaths in the resuscitation group, whereas there were 9 deaths in the control group; however, there was no statistically significant difference in the mortality rate between the two groups at this time $(p>0.05)$. At 90 min, there were still no deaths in the resuscitation group, whereas there were 18 deaths in the control group $(p<0.01$; Table I).

\section{Comparison of Blood Pressure}

There were no significant changes in the blood pressure at 
Table I. Comparison of the mortality rates between the two groups treated with different reinfusion methods at different time points after establishing the rabbit model of hemorrhagic shock

\begin{tabular}{|c|c|c|c|c|c|}
\hline \multirow[t]{2}{*}{ Group } & \multirow[t]{2}{*}{ No. of animals } & \multicolumn{4}{|c|}{ Mortality rate (\% [no. of animals]) } \\
\hline & & $0 \mathrm{~min}$ & $30 \mathrm{~min}$ & $60 \mathrm{~min}$ & $90 \mathrm{~min}$ \\
\hline Resuscitation group & 30 & $0(0)$ & $0(0)$ & $0(0)$ & $0(0)$ \\
\hline Control group & 30 & $0(0)$ & $0(0)$ & $30(9)$ & $60(18)$ \\
\hline$\chi^{2}$ value & & & & 3.529 & 8.571 \\
\hline$P$ value & & & & 0.060 & 0.003 \\
\hline
\end{tabular}

The resuscitation group received pulsed carotid artery reinfusion, and the control group received pulsed intravenous reinfusion. The resuscitation began at $60 \mathrm{~min}$. Non-applicable values are left as blanks in this table.

0 and 30 min after the hemorrhagic shock model was established ( $p>0.05$ for both). MAP and pulse pressure of the rabbits in the resuscitation group were significantly increased at $60 \mathrm{~min}$ than at $30 \mathrm{~min}$ ( $p<0.05$ for both), whereas in the control group, the blood pressure was constantly decreasing. From the beginning of the resuscitation, MAP and pulse pressure of rabbits in the resuscitation group were significantly higher than those of rabbits in the control group at all time points $(p<0.0$ I for all; Table 2).

\section{Comparison of Urine Output}

In both groups, there were no significant differences in the urine output between 0 and $30 \mathrm{~min}$ after the hemorrhagic shock model was established ( $p>0.05$ for both). At 60 and 90 $\mathrm{min}$, the urine output of the rabbits in the resuscitation group was significantly increased when compared to that at $30 \mathrm{~min}$, although it was lower than that at $0 \mathrm{~min}(\mathrm{p}<0.05$ for all). Conversely, in the control group, the urine output decreased constantly. From the beginning of the resuscitation, the urine output of the rabbits in the resuscitation group was significantly higher than that of the rabbits in the control group at all time points $(p<0.0$ I for all; Table 3$)$.

\section{Comparison of Blood Lactate Levels}

In both groups, there were no significant differences in the blood lactate levels between 0 and $30 \mathrm{~min}$ after the hemor-

Table 2. Comparison of the dynamic changes in blood pressure between the two groups treated with different reinfusion methods at different time points after establishing the rabbit model of hemorrhagic shock (Mean \pm SD)

\begin{tabular}{|c|c|c|c|c|c|c|c|c|}
\hline \multirow[t]{2}{*}{ Group } & \multicolumn{4}{|c|}{ Mean arterial pressure ( $\mathrm{mmHg}$ [no. of animals]) } & \multicolumn{4}{|c|}{ Pulse pressure (mmHg [no. of animals]) } \\
\hline & $0 \mathrm{~min}$ & $30 \mathrm{~min}$ & $60 \mathrm{~min}$ & $90 \mathrm{~min}$ & $0 \mathrm{~min}$ & $30 \mathrm{~min}$ & $60 \mathrm{~min}$ & $90 \mathrm{~min}$ \\
\hline Resuscitation group & $103.15 \pm 1.54(30)$ & $50.41 \pm 1.89(30)$ & $83.67 \pm 3.90(30)^{\mathrm{a}}$ & $78.61 \pm 4.76(30)^{\mathrm{a}}$ & $23.61 \pm 2.74(30)$ & $11.39 \pm 1.28(30)$ & $16.46 \pm 2.21(30)^{\mathrm{a}}$ & $16.24 \pm 2.07(30)^{\mathrm{a}}$ \\
\hline Control group & $102.65 \pm 1.87(30)$ & $49.47 \pm 3.71(30)$ & $38.19 \pm 3.50(31)$ & $22.36 \pm 4.49(12)$ & $22.99 \pm 2.38(30)$ & $11.38 \pm 1.14(30)$ & $10.27 \pm 2.99(21)$ & $7.37 \pm 1.05(12)$ \\
\hline $\mathrm{t}$ value & 0.206 & 0.715 & 24.672 & 0.206 & 0.540 & 0.020 & 4.873 & 8.042 \\
\hline$P$ value & 0.839 & 0.484 & 0.000 & 0.000 & 0.596 & 0.984 & 0.000 & 0.000 \\
\hline
\end{tabular}

The resuscitation group received pulsed carotid artery reinfusion, and the control group received pulsed intravenous reinfusion. Resuscitation began at 60 min. The value at 60 min was compared with that at $30 \mathrm{~min}$ within each group ( $\mathrm{p}<0.05 \mathrm{for}$ all). The number of animals is recorded within parentheses. al $\mathrm{mmHg}=0.133 \mathrm{kPa}$.

Table 3. Comparison of the dynamic changes in urine output between the two groups treated with different reinfusion methods at different time points after establishing the rabbit model of hemorrhagic shock (Mean \pm SD)

\begin{tabular}{|c|c|c|c|c|}
\hline \multirow[t]{2}{*}{ Group } & \multicolumn{4}{|c|}{ Urine output $(\mathrm{mL} \cdot \mathrm{kg}-I \cdot \mathrm{min}-\mathrm{I}$, Mean $\pm S D$ [no. of animals]) } \\
\hline & 0 min & $30 \mathrm{~min}$ & $60 \mathrm{~min}$ & $90 \mathrm{~min}$ \\
\hline Resuscitation group & $23.674 \pm 2.891(30)$ & $0.282 \pm 0.157(30)$ & $3.683 \pm 0.740(30)^{\mathrm{a}, \mathrm{b}}$ & $2.262 \pm 0.496(30)^{a, b}$ \\
\hline Control group & $24.786 \pm 2.604(30)$ & $0.298 \pm 0.205(30)$ & $0.100 \pm 0.054(21)$ & $0.010 \pm 0.008(12)$ \\
\hline $\mathrm{t}$ value & -0.904 & -0.196 & 12.653 & 8.866 \\
\hline$P$ value & 0.378 & 0.847 & 0.000 & 0.000 \\
\hline
\end{tabular}

The resuscitation group received pulsed carotid artery reinfusion, and the control group received pulsed intravenous reinfusion. Resuscitation began at 60 min. The value at $60 \mathrm{~min}$ was compared with that at $0 \mathrm{~min}\left({ }^{\mathrm{a}} \mathrm{p}<0.05\right)$ and at $30 \mathrm{~min}$ within each group $\left({ }^{\mathrm{b}} \mathrm{p}<0.05\right)$. The number of animals is recorded within parentheses. 
Table 4. Comparison of the dynamic changes in blood lactate levels and lactate clearance rates between the two groups treated with different reinfusion methods at different time points after establishing the rabbit model of hemorrhagic shock (Mean \pm SD)

\begin{tabular}{|c|c|c|c|c|c|c|}
\hline \multirow[t]{2}{*}{ Group } & \multicolumn{4}{|c|}{ Blood Lactate Levels (mmol/L [no. of animals]) } & \multicolumn{2}{|c|}{ Lactate clearance rate ( $\%$ [no. of animals]) } \\
\hline & $0 \mathrm{~min}$ & $30 \mathrm{~min}$ & $60 \mathrm{~min}$ & $90 \mathrm{~min}$ & $30 \mathrm{~min}$ & $60 \mathrm{~min}$ \\
\hline Resuscitation group & $2.85 \pm 0.15(30)$ & $5.16 \pm 0.42(30)$ & $3.82 \pm 0.50(30)^{\mathrm{a}}$ & $3.60 \pm 0.47(30)^{\mathrm{a}}$ & $0.26 \pm 0.11(30)$ & $\mid 6.46 \pm 2.21(30)$ \\
\hline Control group & $2.96 \pm 0.47(30)$ & $5.13 \pm 0.51(30)$ & $6.49 \pm 0.6 I(2 I)$ & $8.70 \pm 0.51(12)$ & $0.25 \pm 0.14(21)$ & $10.27 \pm 2.99(21)$ \\
\hline $\mathrm{t}$ value & -0.661 & -0.421 & -9.916 & -17.924 & -8.442 & -10.822 \\
\hline$P$ value & 0.517 & 0.678 & 0.000 & 0.000 & 0.000 & 0.000 \\
\hline
\end{tabular}

The resuscitation group received pulsed carotid artery reinfusion, and the control group received pulsed intravenous reinfusion. Resuscitation began at 60 min. The value at $60 \mathrm{~min}$ was compared with that at $0 \mathrm{~min}\left({ }^{\mathrm{a}} \mathrm{p}<0.05\right)$. The number of animals is recorded within parentheses.

rhagic shock model was established ( $p>0.05$ for both). From the beginning of the resuscitation, the blood lactate level of the rabbits in the resuscitation group significantly decreased, whereas in the control group, the blood lactate level continued to increase. At the beginning of the resuscitation, the blood lactate level of the rabbits in the resuscitation group was significantly decreased when compared with that of the control group, and the trend lasted until $90 \mathrm{~min}$ ( $p<0.01$ for all). Moreover, at 30 and $60 \mathrm{~min}$ after the model was established, the lactate clearance rate of rabbits in the resuscitation group was significantly higher than that of the rabbits in the control group ( $p<0.0$ l for both; Table 4$)$.

\section{DISCUSSION}

Traditionally, a large influx of liquid is allowed into the systemic circulation within a short period of time, and this increase in circulating blood volume is beneficial for the maintenance of arterial blood pressure. ${ }^{[18,19]}$ However, a sudden influx of liquid into the blood vessels will cause the infused blood to be retained in the venous system as the blood is in a state of stasis in the capillaries, which will cause a constant increase in the intravascular hydrostatic pressure..$^{[13,20-22]}$ In turn, this results in more intravascular liquid penetrating into the extravascular space through the blood vessel walls, which already show increased permeability due to the ischemic and hypoxic injury. Consequently, this process can cause edema of the internal organs, especially pulmonary edema. ${ }^{[2,15,23]}$ which further aggravates the hypoxemia. In addition, this massive infusion of liquid may also lead to heart failure, thus creating a vicious cycle. ${ }^{[4,23-26]}$ Further, after acute major bleeding, the peripheral veins will collapse, and phlebotomy or deep vein puncture will take a long time to complete. Hence, in some cases, the intravenous infusion rate cannot meet the needs of resuscitation. ${ }^{\left[{ }^{\prime \prime}\right]}$ Under these circumstances, other procedures, besides intravenous infusion, are needed for rapid infusion, and arterial resuscitation provides a feasible option for emergency resuscitation.

There have been some reports on arterial blood transfusion. However, because of its complex nature and risk of adverse reactions such as vasospasm and limb ischemia, it is currently only used as a backup plan in cases of severe shock, acute blood loss, near-death state, and clinical death. ${ }^{[6,17,27]}$ In this study, during the process of preparing the hemorrhagic shock model, the average blood loss of the experimental animals was $25 \mathrm{~mL} / \mathrm{kg}$, and MAP decreased to $50 \%$ of the baseline value and stabilized at approximately $50 \mathrm{mmHg}$. MAP, pulse pressure, urine output, and blood lactate levels showed significant changes, indicating that the model met the requirements and was accurate. After the blood was partially reinfused by pulsed arterial reinfusion, MAP increased significantly, and in some rabbits, MAP could even be restored to the level before the shock. In addition, the pulse pressure also significantly increased and could be maintained for a long period of time.

It is generally considered that pulse pressure has a close relationship with tissue perfusion. ${ }^{[12]}$ In this study, the urine output in the resuscitation group was found to significantly increase as well, indicating that the renal perfusion of the experimental rabbits was partially restored. Furthermore, the blood lactate level of the experimental animals decreased, suggesting that hypoxemia, which appeared from the onset of the shock and was aggravated throughout the experiment, was restored to a certain degree.

Only after the oxygen debt is repaid, tissue acidosis can be corrected; for shock resuscitation to be considered complete, the aerobic metabolism needs to be recovered in addition to the hemodynamic parameters. Our results suggested that pulsed arterial blood reinfusion could increase pulse pressure, elevate tissue perfusion, and alleviate hypoxemia in a rabbit model of shock. Hypoxemia has always been considered the root cause of complications in shock and the major cause of mortality in these rabbits. ${ }^{[13,15,17]}$ Therefore, it is reasonable to believe that the application of pulsed arterial blood reinfusion may reduce early mortality in patients with hemorrhagic shock, while also having positive effects on the incidence of complications due to shock and late mortality. ${ }^{[13,28,29]}$

In addition to rapidly increasing the effective circulating blood volume, arterial blood transfusion can pump the 
blood directly into the aorta, from where most of the blood is directly transported to various organs in need, particularly including the heart, brain, and kidneys; this process can rapidly improve the ischemic and hypoxic status of the body. [15,24] The direct supply of blood to the brain through the carotid tissues is beneficial to the recovery of vital medullary life functions, consequently improving the functioning of the central nervous system, especially that of the cortex and subcortical regions and thereby restoring the regulatory functions that were initially interfered with. ${ }^{[27,30]}$ As the blood is infused under added arterial pressure, which does not rely on the function of the heart that is already fragile, the burden placed on the heart is relieved. Furthermore, because the infused arterial blood can directly flow into the coronary arteries, this also alleviates the myocardial ischemia and facilitates the recovery of cardiac function. ${ }^{[27,30]}$ The blood that flows through the aorta quickly enters the kidneys, gastrointestinal tract, and other organs, thus increasing the blood perfusion, protecting the function of the internal organs, and slowing down the systemic inflammatory response syndrome, as well as reducing the risks of intestinal bacterial translocation and intestinal endotoxemia. Because the transfused blood in the artery flows retrogradely, it forms turbulences in the large vessels (similar to ventricle turbulence), which helps to mix the blood thoroughly. Therefore, the oxygen content of the blood transported to the various organs will not increase too abruptly, thus creating a buffer allowing for a gradual increase of oxygen content in the body. This helps reduce ischemia and reperfusion injury and can hence help reduce the risks of visceral and pulmonary edemas. ${ }^{[13,27,30]}$

Moreover, the pressurized transfusion of arterial blood constantly stimulates the vessel walls, including the chemical receptors and baroreceptors of the aortic arch and carotid sinus. The reflex protection system of the body and the vagal reflex from the direct stimulation of blood on the arterial wall can result in a significant elevation of arterial pressure ${ }^{[29,31]}$ and lead to high blood pressure at the arterial end of the capillaries, which helps reduce capillary congestion. The decrease in heart rate induced by this reflex may increase the pulse pressure, improve the cardiac ejection capability, and eventually augment the tissue perfusion pressure; visceral vasodilation induced by this reflex also helps improve the visceral blood perfusion. A small proportion of the retrograde blood flows into the heart ventricle, thereby prolonging ventricular isovolumic relaxation and promoting rapid closure of the semilunar valves. As a result, the ventricular pressure will decrease sharply, thus forming a large suction force as the main driving force of rapid ventricular filling. This force will cause increased blood flow from the left atrium into the left ventricle, which helps alleviate venous congestion, and will also increase the left ventricular end-diastolic volume. Myocardial contractility is strengthened through self-regulation, and the diastolic extension is also conducive to coronary blood supply, thus forming a virtuous circle.
As a result of pulsed arterial blood transfusion, the negative effect of stimulating the blood vessel wall is reduced and the occurrence of vasospasm is decreased. Mild protective vasospasm helps increase peripheral resistance to increase blood pressure and will not affect the ability of blood vessels to transport blood. Moreover, pulsed arterial blood transfusion may also help reduce endothelial injury, maintain endothelial secretion and barrier functions, reduce blood vessel wall inflammation, and reduce the risk of thrombosis. ${ }^{[32]}$ The pulsed procedure stimulates the aortic arch and chemical receptors to preserve them in a sensitive state, and therefore, resetting will not occur. Meanwhile, the pulsed procedure does not result in constant stimulation of the vagus nerve to cause hyperexcitability and will hence not cause a reduction in the cardiac ejection blood volume to aggravate low blood pressure. This reduces the blood pressure fluctuations as well as the interference on the hemodynamics and on the body's own regulation during the buffering period. ${ }^{[22,32]}$

Lastly, blood (especially autologous blood, including uncontaminated body cavity blood and frozen plasma extracted and prepared in advance from high-risk groups such as soldiers) [25-27] has always been considered the best and most effective resuscitation solution. Apart from momentarily increasing blood volume and reducing apoptosis, the blood can moreover supplement coagulation factors, which help control bleeding.

\section{Conclusion}

With the recent advancements in arterial puncture technology, arterial resuscitation can enable direct transportation of blood to the heart, brain, kidneys, and other organs, thereby greatly reducing the reliance on cardiac function. Therefore, pulsed arterial resuscitation might be useful for the emergency treatment of hemorrhagic shock. However, further studies and discussions are still needed on whether pulsed arterial resuscitation can improve the clinical cure rate and reduce mortality.

\section{Acknowledgments}

The present study was supported by the Health and Familly Plannning Comission of Zhejiang Province, China (No.20I4RCA023) and Science and Technology Department of Hangzhou, China (No.20I20533Q22, 20I50733Q I8).

\section{Conflict of interest: None declared.}

\section{REFERENCES}

1. Xu H, Han LC, Gao W, Sun XX, Zhou Y, Meng XZ, et al. Therapeutic effects of intravenous infusion of hyperoxygenated solution on acute haemorrhagic shock in rabbits. J Int Med Res 2011;39:1843-51.

2. Prunet B, Prat N, Couret D, Cordier PY, De Bourmont S, Lambert D, et al. Midterm effects of fluid resuscitation strategies in an experimental model of lung contusion and hemorrhagic shock. Shock 2014;41:15965. [CrossRef] 
3. Lu XG, Kang X, Zhou FQ, Wang XZ, Guo S, Fan ZW, et al. Effects of pyruvate-enriched peritoneal dialysis solution on intestinal barrier in peritoneal resuscitation from hemorrhagic shock in rats. J Surg Res 2015;193:368-76. [CrossRef]

4. Lee JH, Kim K, Jo YH, Kim MA, Lee KB, Rhee JE, et al. Blood pressuretargeted stepwise resuscitation for hemorrhagic shock in rats. J Trauma Acute Care Surg 2014;76:771-8. [CrossRef]

5. Kosaka J, Morimatsu H, Takahashi T, Shimizu H, Kawanishi S, Omori E, et al. Effects of biliverdin administration on acute lung injury induced by hemorrhagic shock and resuscitation in rats. PLoS One 2013;8:e63606.

6. Baron DM, Beloiartsev A, Nakagawa A, Martyn T, Stowell CP, Malhotra $\mathrm{R}$, et al. Adverse effects of hemorrhagic shock resuscitation with stored blood are ameliorated by inhaled nitric oxide in lambs*. Crit Care Med 2013;41:2492-501. [CrossRef]

7. Vigani A, Shih A, Queiroz P, Pariaut R, Gabrielli A, Thuramalla N, et al. Quantitative response of volumetric variables measured by a new ultrasound dilution method in a juvenile model of hemorrhagic shock and resuscitation. Resuscitation 2012;83:1031-7. [CrossRef]

8. Cemil B, Gökce EC, Erdamar H, Karabörk A, Onur O, Heper Okcu A, et al. Effects of the aged garlic extract on spinal cord injury model in rat. Ulus Travma Acil Cerrahi Derg 2012;18:463-8. [CrossRef]

9. Almac E, Aksu U, Bezemer R, Jong W, Kandil A, Yuruk K, et al. The acute effects of acetate-balanced colloid and crystalloid resuscitation on renal oxygenation in a rat model of hemorrhagic shock. Resuscitation 2012;83:1166-72. [CrossRef]

10. Takasu A, Shibata M, Uchino S, Nishi K, Yamamoto Y, Sakamoto T. Effects of arterial oxygen content on oxidative stress during resuscitation in a rat hemorrhagic shock model. Resuscitation 2011;82:110-4. [CrossRef]

11. Pierce JD, Knight AR, Slusser JG, Gajewski BJ, Clancy RL. Effects of fluid resuscitation and dopamine on diaphragm performance, hydrogen peroxide, and apoptosis following hemorrhagic shock in a rat model. Mil Med 2011;176:336-42. [CrossRef]

12. Li J, Beiser DG, Wang H, Das A, Berdyshev E, Li J, et al. Therapeutic hypothermia cardioprotection in murine hemorrhagic shock/resuscitation differentially affects $\mathrm{p} 38 \alpha / \mathrm{p} 38 \gamma$, Akt, and HspB1. J Trauma 2011;71:1262-70. [CrossRef]

13. Wang CH1, Hsieh WH, Chou HC, Huang YS, Shen JH, Yeo YH, et al. Liberal versus restricted fluid resuscitation strategies in trauma patients: a systematic review and meta-analysis of randomized controlled trials and observational studies* ${ }^{*}$ Crit Care Med 2014;42:954-61. [CrossRef]

14. Németh M, Tánczos K, Demeter G, Erces D, Kaszaki J, Mikor A, et al. Central venous oxygen saturation and carbon dioxide gap as resuscitation targets in a hemorrhagic shock. Acta Anaesthesiol Scand 2014;58:6119. [CrossRef]

15. Murdock AD, Berséus O, Hervig T, Strandenes G, Lunde TH. Whole blood: the future of traumatic hemorrhagic shock resuscitation. Shock 2014;41 Suppl 1:62-9. [CrossRef]

16. Douzinas EE, Livaditi O, Tasoulis MK, Prigouris P, Bakos D, Goutas N, et al. Nitrosative and oxidative stresses contribute to post-ischemic liver injury following severe hemorrhagic shock: the role of hypoxemic resuscitation. PLoS One 2012; 7:e32968. [CrossRef]

17. Urbano J, González R, López J, Solana MJ, Bellón JM, Botrán M, et al. Comparison of normal saline, hypertonic saline albumin and terlipressin plus hypertonic saline albumin in an infant animal model of hypovolemic shock. PLoS One 2015;10:e0121678. [CrossRef]
18. Hu S, Ma L, Luo HM, Lin ZL, Wang XQ, Jia YH, et al. Pyruvate is superior to reverse visceral hypoperfusion in peritoneal resuscitation from hemorrhagic shock in rats. Shock 2014;41:355-61. [CrossRef]

19. Saeedi M, Hajiseyedjavadi H, Vahdati SS, Eslami V, Mokhtarpour M, Momeni M, et al. Hypertonic saline, normal saline or neither: which is best for uncontrolled hemorrhagic shock? An experimental study in goats. Ulus Travma Acil Cerrahi Derg 2013;19:500-6. [CrossRef]

20. Wernick MB, Steinmetz HW, Martin-Jurado O, Howard J, Vogler B, Vogt R, et al. Comparison of fluid types for resuscitation in acute hemorrhagic shock and evaluation of gastric luminal and transcutaneous Pco2 in Leghorn chickens. J Avian Med Surg 2013;27:109-19. [CrossRef]

21. Torres LN, Sondeen JL, Ji L, Dubick MA, Torres Filho I. Evaluation of resuscitation fluids on endothelial glycocalyx, venular blood flow, and coagulation function after hemorrhagic shock in rats. J Trauma Acute Care Surg 2013;75:759-66. [CrossRef]

22. Pottecher J, Chemla D, Xavier L, Liu N, Chazot T, Marescaux J, et al. The pulse pressure/heart rate ratio as a marker of stroke volume changes during hemorrhagic shock and resuscitation in anesthetized swine. J Trauma Acute Care Surg 2013;74:1438-45. [CrossRef]

23. Lee CC, Lee MT, Chang SS, Lee SH, Huang YC, Yo CH, et al. A comparison of vasopressin, terlipressin, and lactated ringers for resuscitation of uncontrolled hemorrhagic shock in an animal model. PLoS One 2014;9:e95821. [CrossRef]

24. Noel-Morgan J, Otsuki DA, Auler JO Jr, Fukushima JT, Fantoni DT. Pulse pressure variation is comparable with central venous pressure to guide fluid resuscitation in experimental hemorrhagic shock with endotoxemia. Shock 2013;40:303-11. [CrossRef]

25. Aksu U, Bezemer R, Yavuz B, Kandil A, Demirci C, Ince C. Balanced vs unbalanced crystalloid resuscitation in a near-fatal model of hemorrhagic shock and the effects on renal oxygenation, oxidative stress, and inflammation. Resuscitation 2012;83:767-73. [CrossRef]

26. Martini WZ, Cortez DS, Dubick MA. Comparisons of normal saline and lactated Ringer's resuscitation on hemodynamics, metabolic responses, and coagulation in pigs after severe hemorrhagic shock. Scand J Trauma Resusc Emerg Med 2013;21:86. [CrossRef]

27. Elbers P, Gatz R. Crystalloid resuscitation in hemorrhagic shock. Resuscitation 2012;83:e172. [CrossRef]

28. Gao J, Zhou L, Ge Y, Lin S, Du J. Effects of different resuscitation fluids on pulmonary expression of aquaporin 1 and aquaporin 5 in a rat model of uncontrolled hemorrhagic shock and infection. PLoS One 2013;8:e64390. [CrossRef]

29. Sloan EP, Koenigsberg MD, Philbin NB, Gao W. Diaspirin cross-linked hemoglobin infusion did not influence base deficit and lactic acid levels in two clinical trials of traumatic hemorrhagic shock patient resuscitation.J Trauma 2010;68:1158-71. [CrossRef]

30. Kendigelen P, Kamalak Z, Abat D. Should warm fresh whole blood be the first choice in acute massive hemorrhage in emergency conditions? Ulus Travma Acil Cerrahi Derg 2016;22:195-8.

31. Balbino M, Capone Neto A, Prist R, Ferreira AT, Poli-de-Figueiredo LF. Fluid resuscitation with isotonic or hypertonic saline solution avoids intraneural calcium influx after traumatic brain injury associated with hemorrhagic shock. J Trauma 2010;68:859-64. [CrossRef]

32. DU Z, Jia H, Liu J, Zhao X, Wang Y, Sun X. Protective effects of hydrogen-rich saline in uncontrolled hemorrhagic shock. Exp Ther Med 2014;7:1253-8. [CrossRef] 


\section{DENEYSEL ÇALIŞMA - ÖZET}

\section{Tavşan hemorajik şok modelinde atımlı arteriyel resüsitasyon uygulaması}

\section{Dr. Wendong Sun, ${ }^{1}$ Dr. Zhihui Shao, ${ }^{2}$ Dr. Haisong Xu, ${ }^{2}$ Dr. Wusi Qiu, ${ }^{2}$ Dr. Jiahua Sun ${ }^{2}$}

${ }^{1}$ Shaoxing Halk Hastanesi, Zhejiang Üniversitesi Shaoxing Hastanesi, Ortopedi Bölümü, Shaoxing-Çin Halk Cumhuriyeti ${ }^{2}$ Hangzhou İkinci Hastanesi, Hangzhou Normal Üniversitesi Tıp Fakültesi, Nöroşirürji Bölümü, Hangzhou-Çin Halk Cumhuriyeti

AMAÇ: Hemorajik şok dolaşımdaki etkin kan volümünde aniden azalmanın neden olduğu doku hipoperfüzyonuyla karakterizedir. Resüsitasyonun anahtarı mümkün olduğu kadar kısa sürede şokun ortadan kaldııımasıyla birlikte aynı anda yaşamsal organlara kan perfüzyonunu sağlamadaki başarıdır. Biz burada hemorajik şok resüsitasyonunda atımlı arteriyel kan reperfüzyonunun uygulanabilirlik durumunu sunmaktayız.

GEREÇ VE YÖNTEM: Altmış tavşan randomize yöntemle resüsitasyon ve kontrol gruplarına ayrıldı. Karotis arterden kan akıtılarak hemorajik şok modeli geliştirilmişti. Kan basıncı, idrar çıkarımı, kan laktat ve diğer belirteçlerdeki dinamik değişiklikler ölçüldü.

BULGULAR: Kontrol grubuyla karşılaştıııldı̆ında, 60. dakikada resüsitasyon grubunda OAB, nabız basıncı ve idrar çıkarımı anlamlı derecede daha

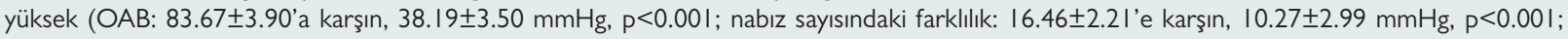
idrar miktarı: $3.68 \pm 0.74$ 'e karşın, $\left.0.10 \pm 0.05 \mathrm{~mL} \cdot \mathrm{kg}^{-1} \cdot \mathrm{dk}^{-1}, \mathrm{p}<0.00 \mathrm{I}\right)$, serum laktat düzeyi ise anlamlı derecede daha düşüktü $(3.82 \pm 0.50$ 'e karşın $6.49 \pm 0.6 \mathrm{I} \mathrm{mmol} / \mathrm{L}, \mathrm{p}<0.00 \mathrm{I})$. Ayrıca resüsitasyon grubunda laktat klirens oranı anlamlı derecede daha yüksekti $(30 \mathrm{dk}$ : \%0.26 $\pm 0.1 \mathrm{l}$ 'e karşın

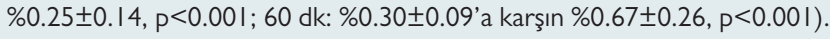

TARTIŞMA: Hemorajik şokun acilen tedavisinde atımlı arteriyel resüsitasyon kullanılabilir.

Anahtar sözcükler: Arter; hemorajik şok; nabız; resüsitasyon.

Ulus Travma Acil Cerrahi Derg 2017;23(6):445-45। doi: 10.5505/tjtes.2017.99567 